\title{
Agroforestry Pattern in Peatland of Ex-Transmigration in Kalampangan Village of Sabangau Sub District Palangkaraya Central Kalimantan Province
}

\author{
Daniel Itta, Yudi Firmanul Arifin, Abd. Latief Abadi, Maryunani \\ (Economics, Brawijaya University, Indonesia)
}

\section{Introduction}

Peatland is a land that lacks in nutrients. This deficiency causes some new problems if it is not cultivated wisely. On the other hand, it is necessary to think of how this wide area of peatland can be utilized by the community to improve their prosperity. Kalampangan Village was the location of a transmigration unit (Unit Pemukiman Transmigrasi Bereng Bengkel) from 1980. The utilization of the peatland should be managed carefully and wisely so that it will not cause any new problem such as the degradation of soil surface. The research of the agroforestry pattern aims to find out the economical value of a land and the suitable agroforestry pattern applied in the ombrogen peatland. The agroforestry pattern is one of the alternatives to utilize the peatland in addition to the forestry crops, which are insitu crops, combined with agricultural crops.

Peatland is considered the problematic land since it has marginal properties and possesses some constraints if it is cultivated as farming land. The constraints are: 1) it has low bearing capacity, so it makes difficult for the crop to firmly anchor its root; 2) it has hydraulic conductivity, which is quite big horizontally but quite small vertically, so it makes difficult for the mobility of water and the crop nutrient; 3) it is irreversible, so it decreases the water retention capacity and is sensitive to erosion resulting in the easiness of it to be washed; 4) the land surface declines after dried or utilized. Hence, the utilization of peatland for agrobusiness requires special knowledge and technology due to its special and distinct properties compared to other types of lands, which are generally the alluvial lands. (Noor et al, 1991 in Noorginayuwati et al, 2008).

According to Wijaya Adhi et al (1998) the policy of the peatland utilization requires many efforts and supports, such as from the researches. In this sense, the patterns conducted by the farmers and the patterns of the utilization based on agroforestry that have been carried out by community need to be studied. The utilization of natural resources must be conducted optimally and friendly environmentally because the optimal utilization will shore up the local economy while the environmentally friendly utilization will prevent the natural resources from damage, which eventually will influence the ecological balance essential for all life systems. If the quality of the environment decreases exceeding the supporting capacity, the economy will lose its capacity to grow (Azis, 2006). The natural and environmental resources are important elements, and influence the economic growth.

The agroforestry pattern is the system of land utilization including the mixture, which is socially and ecologically accepted, between trees and agricultural crops as well as/ or livestock all together or respectively to increase the crop productivity and livestock sustainability from the farming land unit, especially under the condition of simple technology and marginal land (Nair, 1989 in Lahjie, 2004). Agroforestry is a system forming that is complex and impossible to understand partially if merely among the components. The interaction among the components requires a comprehensive reasoning by considering all the components simultaneously.

The agroforestry pattern has ecological, economical, and social benefits. Its benefits are: the decrease of the pressure toward forests; the more efficient recycle of nutrients; the increase of soil nutrients and the improvement of soil structure; the increase of the sustainability of food, firewood, livestock feed and timber; the increase of farmers' income; and the increase of nutrition and health through the increasing of the quality and the variety of food (Lahjie, 2004).

The management of the degraded land of ex-transmigration through agroforestry pattern is one of the land management systems, which is expected to be able to provide the community with the balance of ecological, economical, and social benefits. The pattern of agroforestry in the peatland of ex-transmigration is expected to able to help address the need of timber by still considering the environmental sustainability and welfare, and to support rehabilitation program of forest and land.

Therefore, it is necessary to apply technological breakthroughs such as the induction of crop varieties and the planting combination of some kinds of potential crops in the peatland of ex-transmigration. The provision of organic fertilizers enables to neutralize the $\mathrm{pH}$ (acidity) of soil and absorbs the nutrients from the air around the ground. The understanding of the characteristics of the crops and the woody plants includes the distribution of roots, stems, leaves, canopy, phenology in order to understand the distribution of nutrients, water 
and light in the agroforestry pattern. Regarding to the properties of peat characteristics, which is very complex and varies, the research of agroforestry techniques should be site specific by considering the environmental physical properties, the social aspects, the culture, the tradition and the local wisdom.

The intercrops in the agroforestry pattern can ecologically help to upgrade the soil fertile for the growth of staple crops and are economically the resource of short-term income for farmers while waiting for the yield of staple crops. The products can be tangible and intangible (Suharjito, 2003 in Jawawi, 2007).

The focus of the research, which is to rehabilitate the degraded peatland, is more on how to grow plants well and maintained by the activities of farmers in the crop management, therefore the implementation of agroforestry has not yet comprehensively increased the land productivity and the economy of the farmers. On the other hand, the agroforestry plot, which has been built, should be utilized in the research of agroforestry to improve the economy of the farmers.

Along with the problems mentioned above, it is necessary to conduct the study of the utilization of the peat swamp with the agroforestry pattern. The integrative research of the aspects of cultivation and economy is expected to be able to increase the productivity of the wood and the environmental quality as well as the economical value of the community forest, which supports the timber industry and the economy of the people.

\section{Research Methods}

This research was carried out in the village of Kalampangan Sub-district Sabangau Palangka Raya, Central Kalimantan Province, Indonesia. This research was designed using quantitative design format. Data analysis tools on this research use to analysis of economical value of agroforestry pattern, analysis of revenue of food crops, and agroforestry pattern (Andayani, 2005). The procedures in this study, including the determining the plot of the research, calculating the cost of the land cultivation, measuring the staple crops and intercrops (seasonal crops), calculating the operational cost including the provision of fertilizers either lime or manure, and calculating the economical value of staple crops and intercrops

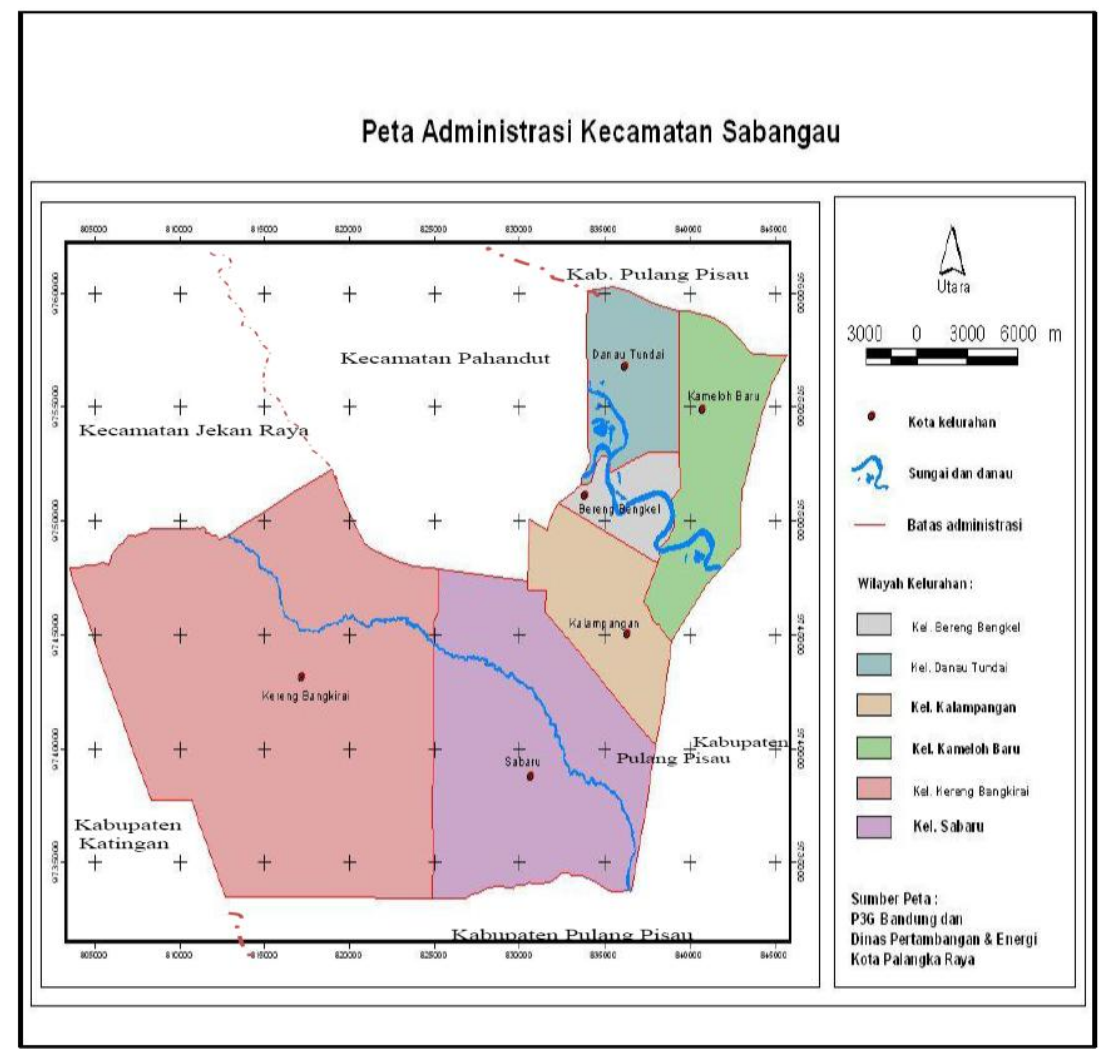

Fig.1. Research Location Map

\section{Empirical Result}

The economical value of the intercrops is the result of the B/C Ratio analysis of each intercrop, where $\mathrm{B} / \mathrm{C}$ ratio is the comparison between the benefit and the operational cost. The result of the analysis is presented in detail on Table 1 
Table.1. Economical Value of Agroforestry Pattern

\begin{tabular}{|l|l|c|c|}
\hline No & \multicolumn{1}{|c|}{ Treatment } & $\begin{array}{c}\text { Value of B/C } \\
\text { Ratio }\end{array}$ & \multicolumn{1}{|c|}{ Information } \\
\hline 1 & Jelutung + Corn (JC) & 1.45 & B/C >1, profitable \\
\hline 2 & Jelutung + Leek (JL) & 1.25 & B/C $>1$, profitable \\
\hline 3 & Jelutung + Green Mustard (JG) & 2.20 & B/C >1, profitable \\
\hline 4 & Jelutung + Chili (JCl) & 1.30 & B/C $>1$, profitable \\
\hline
\end{tabular}

Sources: The result of the primary data analysis

Based on the result, the most profitable intercrop farming is the leek farming with the value of B/C Ratio 2.20 and with shorter age in harvesting, so in one month the farmers can grow intercrops several times.

The production of each kind of intercrop, which is based on agroforestry pattern, is described in Table 2.

Table.2. Intercrop Production and Harvest Time

\begin{tabular}{|l|l|r|r|}
\hline No & \multicolumn{1}{|c|}{ Intercrop } & Production/ 0.1 ha & Harvest Time (day) \\
\hline 1 & Corn $(\mathrm{cob})$ & 2560 & 90 \\
\hline 2 & Green Mustard $(\mathrm{kg})$ & $625=1875$ bunches & 28 \\
\hline 3 & Leek $(\mathrm{kg})$ & 245 & 90 \\
\hline 4 & Chili $(\mathrm{kg})$ & 75 & 120 \\
\hline
\end{tabular}

Sources: The result of the primary data analysis

Table 2 describes the ready-to-harvest age for the corn, the green mustard, the leek and the chili is 90 days, 28 days, 90 days and 120 days, respectively. The harvest time of intercrops should correspond to the crop age. Especially for the green mustard, if it is exceeding the planting age, the vegetables will not be in good condition any more as they rot. Regarding to the harvesting age at every harvest time, the vegetables can be cultivated several times in one year.

The income earned by the farmers in the agroforestry pattern is described in Table 3.

Table.3 Production and Farmers' Income in 0.1 ha for One Season

\begin{tabular}{|l|l|r|r|r|}
\hline No & \multicolumn{1}{|c|}{ Intercrop } & $\begin{array}{c}\text { Production 0.1 } \\
\text { ha }\end{array}$ & Price (Rp) & Income (Rp) \\
\hline 1 & Corn (cob) & 2560 & 1750 & $4,480,000$ \\
\hline 2 & Green Mustard (bunch) & 1875 bunches & 3000 & $5,625,000$ \\
\hline 3 & Leek $(\mathrm{kg})$ & 260 & 8000 & $2,080,000$ \\
\hline 4 & Chili $(\mathrm{kg})$ & 75 & 30,000 & $2,250,000$ \\
\hline
\end{tabular}

Sources: The result of the primary data analysis 2012

Table 3 describes that the green mustard gives the highest income, where the amount of the income for 0.1 ha is $\operatorname{Rp~5,625,000~or~Rp~56,250,000/ha.~Meanwhile~the~lowest~income~is~for~the~leek,~Rp~2,080,000/0.1~ha~}$ or Rp 20,800,000/ha. The main constraint faced by the farmers is the marketing. The prices are based on the estimation of the middlemen on the location. It is not possible for the farmers to market the intercrops by themselves due to the short time especially for the green mustard, which should be immediately harvested. Hence, it is necessary to build a cooperative so that the harvest yield can be stored and be marketed, thus the prices are no longer played by the middlemen, which in turn it will benefit the farmers.

The income that the farmer makes in one year for 0.1 ha is described in Table 4.

Table.4. Production and Income in One Year for 0.1 ha

\begin{tabular}{|l|l|r|r|r|}
\hline No & \multicolumn{1}{|c|}{ Intercrop } & $\begin{array}{c}\text { Production 0.1 } \\
\text { ha }\end{array}$ & Price (Rp) & Income (Rp) \\
\hline 1 & Corn (cob) & 2560 & 1750 & $4,480,000$ \\
\hline 2 & Green Mustard (bunch) & 1875 bunches & 3000 & $5,625,000$ \\
\hline 3 & Leek (kg) & 260 & 8000 & $2,080,000$ \\
\hline 4 & Chili (kg) & 75 & 30,000 & $2,250,000$ \\
\hline
\end{tabular}

Sources: The result of the primary data analysis 2012 
Based on Table 4 the highest income that farmers makes from each intercrop is from the green mustard with $\operatorname{Rp~33,750,000/0.1~ha/year,~and~the~lowest~is~from~the~leek~that~is~Rp~4,500,000/0.1~ha/year.~The~value~of~}$ each intercrop can be changed due to the changes of the prices for each commodity, as a result of the middlemen's role and the number of product each season or harvest. If the harvest is abundance, the price of the commodity will decline. Hence, the farmers should not only rely on one kind of crop.

It is necessary to build market mechanism that benefits the farmers, because so far the prices of the commodity are heavily determined by the middlemen who come to the field. It is also necessary to make the government establish cooperatives in order to store and to market the commodity from the farmers. The difference between the prices in the field and the price in the market is pretty big, but the farmers can not do much about it because the vegetables do not have long durability. They are forced to sell the vegetables with the prices determined by the buyers who come to the field.

Based on the economical value of each kind of intercrop that is observed, the best combination for the staple crop jelutung is green mustard. Jelutung is one of the staple crops that are good in the agroforestry pattern. This is because jelutung has the root that does not widen so it does not disrupt the growth of intercrops, and jelutung also does not have dense canopy. The not-shady canopy is very beneficial to the farmers because it enables the intercropping last longer than other crops like rubber tree. It also does not prevent the sunlight for the crops, see figure 1 and 2.

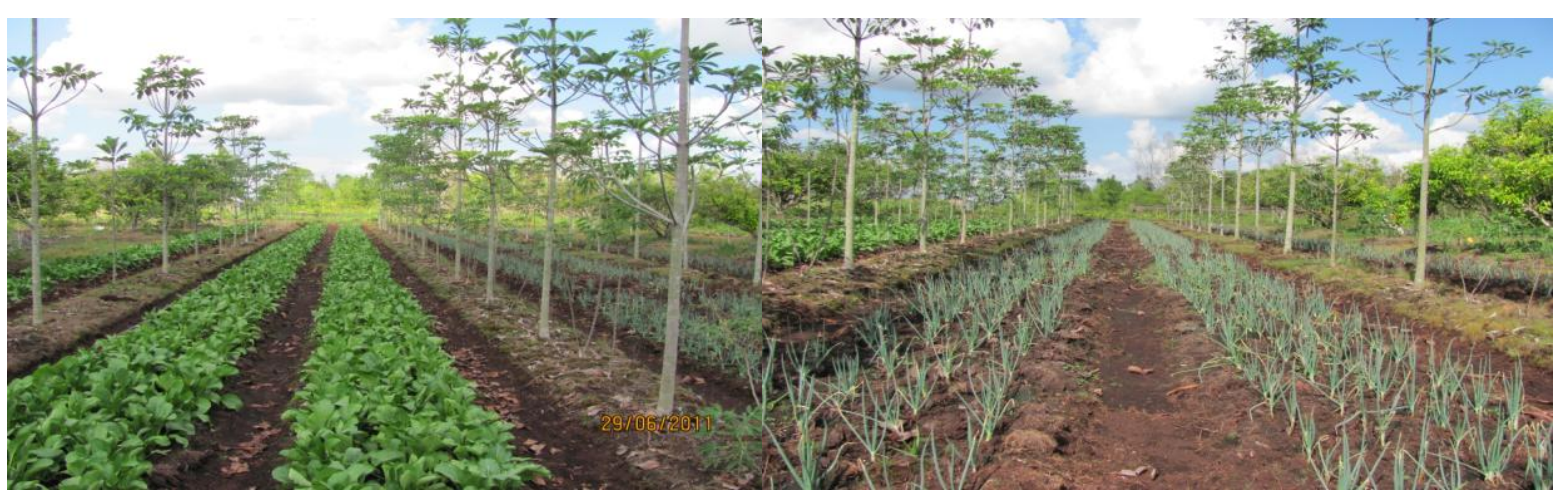

Figure 1. The intercrop of Green Mustard

Figure 2. The intercrop of Leek

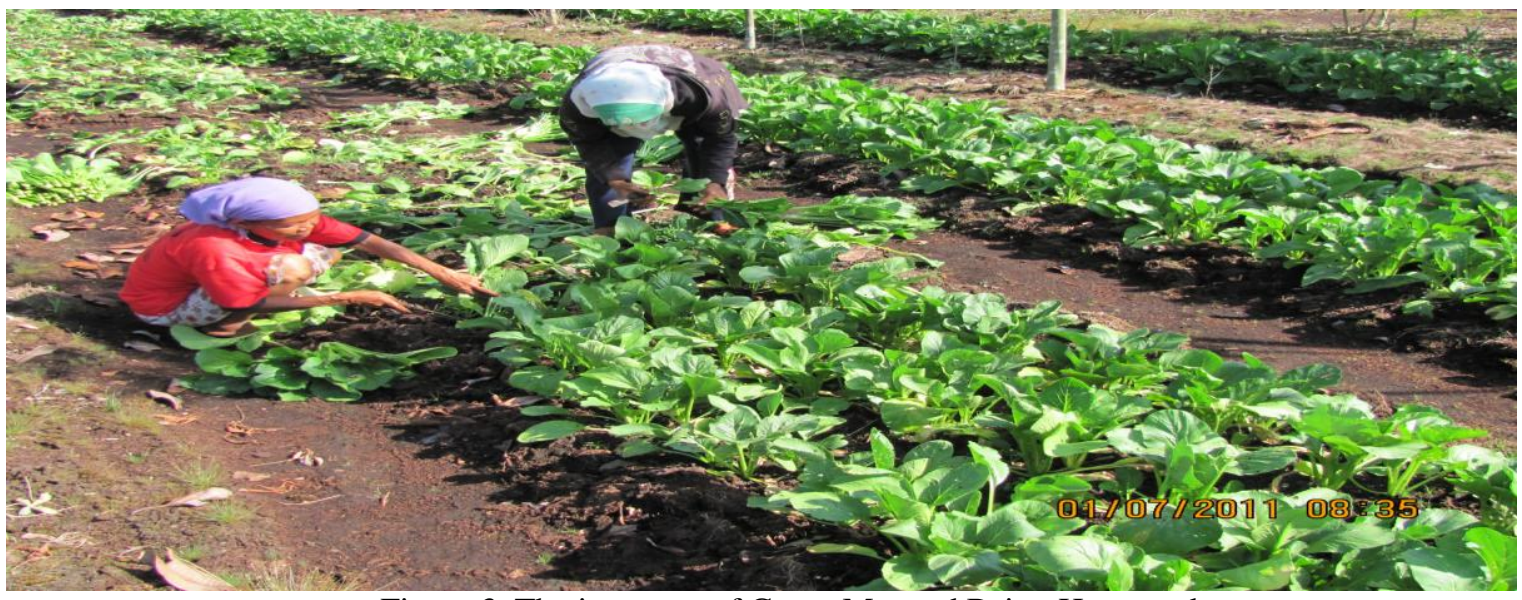

Figure 3. The intercrop of Green Mustard Being Harvested

Considering the harvesting age of the intercrop is not that long, the intercropping is able to be cultivated several times in one year, thus it can be concluded that the agroforestry pattern is very profitable economically.

\section{Conclusions And Suggestions}

Based on the result of the research, it can be concluded that:

1. The intercrops in combination with jelutung in agroforestry pattern have their own economical value. The $\mathrm{B} / \mathrm{C}$ Ratio for the agroindustry pattern of jelutung + corn (JC), jelutung + leek (JL), jelutung + green mustard $(\mathrm{JG})$, and jelutung + chili $(\mathrm{JCl})$ is $1.45,1.25,2.20,1.30$, respectively. The most profitable intercrop is the combination of jelutung and green mustard (B/C Ratio 2.20). 
2. The income from the combination of jelutung + corn is $\mathrm{Rp} 4,480,000 / 0.1$ ha/harvest or equal to $\mathrm{Rp}$ $13,440,000 / 0.1$ ha/year, jelutung + green mustard is $\mathrm{Rp} 5,625,000 / 0.1 \mathrm{ha} / \mathrm{harvest}$ or equal to $\mathrm{Rp}$ $33,759,000 / 0.1 \mathrm{ha} /$ year, jelutung + leek is $\mathrm{Rp} 2,080,000 / 0.1 \mathrm{ha} / \mathrm{harvest}$ or equal to $\mathrm{Rp} 6,240,000 / 0.1$ ha/year, and jelutung + chili is $\mathrm{Rp} 2,250,000 / 0.1$ ha/harvest or equal to $\mathrm{Rp} 4,500,000 / 0.1$ ha/year. The highest income comes from the agroforestry pattern of jelutung + green mustard, namely Rp 5,625,000/0.1 ha/harvest.

3. The most optimal agroforestry pattern is the combination of the staple crop jelutung and green mustard. The utilization of peat swamp through agroforestry pattern can give prospective economical value, which can increase the income of the farmers and save the environment as well.

Based on the result of the research, it is suggested that:

1) The farmers are expected not to burn land to get ash but the use of ash should be replaced with manure to retard the land degradation (subsiden).

2) The farmer should not plant only one kind of intercrops, but there should be some kinds. This is intended to avoid over-production, which will influence the prices.

3) The government should come to think of the way to prevent the middlemen from playing the prices of the commodity by establishing a cooperative that can gather and store all production from farmers.

\section{References}

[1]. Andayani,W, 2005. Ekonomi Agroforestri, Debut Press. Yogyakarta.

[2]. Aziz, 2006. Pendekatan Produktivitas. Conservation Training and Resource Centre, Bogor

[3]. Jawawi, 2007 Penentuan Jenis Berdasarkan Kesesuaian Lahan dalam Rangka Rehabilitasi Hutan dan Lahan Di Sub DAS Teweh Kabupaten Barito Utara Provinsi Kalimantan Tengah. Thesis S2, Banjarbaru, Tidak Dipublikasikan.

[4]. Lahjie, AM. 2004. Teknik Agroforestri. Universitas Mulawarman Samarinda.

[5]. Noorginayuwati,A. Rafieq, Y. Rina, M. Noor dan Achmadi, 2008 Kearifan Budaya Lokal dalam Pemanfaatan Lahan Gambut Untuk Pertanian di Kalimantan. Laporan Hasil Penelitian Balitra. BBSDL.

[6]. Widjaya-Adhi, I.P.G.,K. Nugroho, Dedi Ardi S., dan A. Syarifuddin Karama. 1998. Sumberdaya Lahan Rawa: Potensi, Keterbatasan dan Pemanfaatan dalan Inovasi Teknologi Pertanian Seperempat Abad Penelitian dan Pengembangan Pertanian. Badan Penelitian dan Pengembangan Pertanian. Jakarta. 